\title{
OCASO DA SOCIEDADE CIVIL E DE SEUS MOVIMENTOS: SOBRE A PERDA DE EFETIVIDADE DA CIDADANIA POLÍTICA NAS DEMOCRACIAS O- CIDENTAIS $^{1}$
}

\author{
Leno Francisco Danner (UNIR) ${ }^{2}$ \\ leno_danner@yahoo.com.br
}

Resumo: $\mathrm{O}$ presente artigo discute acerca da evolução das democracias ocidentais no sentido de defender que a consolidação do Estado liberal implicou na negação da sociedade civil e seus movimentos enquanto respectivamente o espaço político e os sujeitos políticos da transformação social por excelência. Ele busca defender que a modernidade política somente foi possível porque a sociedade civil e seus movimentos constituíram-se respectivamente como a arena política por excelência e como os sujeitos políticos por excelência, contra a política e os atores políticos institucionalizados em termos de Antigo Regime. Nesse sentido, a intuição que persigo, ao defender que com o Estado liberal clássico vitorioso nós temos a anulação do potencial político da sociedade civil e de seus movimentos, está em que a estruturação política e social das democracias de massa do capitalismo de regulação estatal, caudatárias desse movimento histórico constituído pelo Estado liberal clássico e pela economia de laissez-faire, apresenta exatamente essa configuração de democracia social e de anulação da democracia política.

Palavras-Chave: sociedade civil, movimentos sociais, estado liberal, democracia.

1. Falar sobre o termo democracia ocidental e com ele querer entender todas as democracias ocidentais poderia parecer

\footnotetext{
${ }^{1}$ Recebido: 15.12.2009/Aprovado em 29.07.2010/Publicado on-line: 30.03.2011.

${ }^{2}$ Leno Francisco Danner é Doutorando em Filosofia pela PUC-RS, Porto Alegre, Rio Grande do Sul e Professor Assistente I na Faculdade de Filosofia da Universidade Federal de Rondônia, Porto Velho, Brasil.
} 
uma tentativa descabida ou desproporcional para qualquer ciência e para qualquer pesquisador, especialmente diante das várias e até divergentes abordagens teóricas acerca dessas democracias e da natureza ou das naturezas dessas democracias. Não obstante, eu vou tentar ser generalista e, com o conceito geral de democracia ocidental, buscarei entender ou pelo menos traçar algumas características gerais de todas as nossas democracias ocidentais. Certamente, a característica que me parece mais interessante para caracterizar esse conceito de democracia ocidental está na separação entre Estado, sociedade civil e economia enquanto esferas particulares, mas integradas. A gênese e o desenvolvimento dos Estados modernos têm efetivamente como um de seus objetivos básicos traçar limites precisos entre essas áreas e sua influência recíproca, de modo que elas possam se encontrar, mas nunca se anular. Então, se nos lembrarmos do pensamento político de Locke, que eu considero o primeiro teórico do Estado moderno (o liberalismo político por ele fundamentado, em minha perspectiva, é a doutrina por excelência do Estado moderno e a primeira a tratar efetivamente da fundamentação do Estado moderno), veremos que ao Estado cabe a função - que lhe é específica - de garantir o respeito aos direitos naturais, de garantir a integridade física e psicológica de cada cidadão, de garantir sua (de cada cidadão) liberdade e de proteger sua (de cada cidadão) propriedade ${ }^{3}$. Teríamos, assim, para este pensador, (1) a sociedade civil (2) organizada em torno da produção e tendo como foco o objetivo, por parte de cada cidadão, de viver sua vida particular (que é para Locke o verdadeiro lugar de realização do indivíduo -

\footnotetext{
${ }^{3}$ Cf.: LOCKE, John. Segundo Tratado sobre o Governo Civil, Livro II, Capítulo I, §03, p. 381.
} 
interessantemente, o trabalho é entendido como uma atividade privada) e (3) o Estado como a instância garantidora desses limites e da proteção necessária à vida de cada um.

Num aspecto muito poderoso, o Estado moderno é construído com o intuito de descentralizar o poder político. Se nos lembrarmos das revoluções inglesa (1685-1689), americana (1776) e Francesa (1789), nelas a questão central estava na formulação de um poder que pudesse sim estar fundado em leis de caráter permanente, duradouro, em leis que enfatizassem a necessidade de consenso majoritário no que diz respeito às decisões políticas centrais, mas que, por outro lado, esse mesmo poder estivesse nas mãos dos próprios cidadãos e/ou de seus representantes nas assembléias. Desse modo, teríamos leis de caráter como que absoluto (substituindo, por exemplo, o poder absoluto do rei), mas decisões de caráter coletivo, o que implicava em que essas mesmas decisões fossem, como eu disse acima, tomadas a partir da regra da maioria, fato que, de acordo com os modernos, poderia garantir um mínimo de eqüidade política que possibilitasse a lisura das decisões políticas. Nota-se, ainda, conforme a formulação de Montesquieu ${ }^{4}$ ou mesmo da Constituição Americana, de $1788^{5}$, a separação entre poderes (executivo, legislativo e judiciário), o que implicava em um complexo caminho até a objetivação de normas e/ou de políticas públicas. A questão toda estava, portanto, na formulação de um poder político que, efetivamente por estar fundado na regra da maioria, perdesse essa sua característica de poder absoluto e, portanto, se descentralizasse,

\footnotetext{
${ }^{4}$ Cf.: MONTESQUIEU, Charles Louis de Secondat, Barão de. O Espírito das Leis, Livro XI, capítulos I-VI, p. 155-162; ARON, Raymond. As Etapas do Pensamento Sociológico, p. 55-85.

${ }^{5}$ Cf.: Constituição Americana. Disponível em: http://www.usconstitution.net/const.html
} 
se diluísse entre os cidadãos e os grupos da sociedade. Essa, segundo penso, é a grande característica do Estado moderno e, por conseqüência, das democracias ocidentais: um poder descentralizado a partir da idéia de que a sociedade civil, o Estado e as atividades produtivas são instâncias independentes, mas ligadas justamente pelo fato de que o Estado garante a proteção dos membros da sociedade civil e o respeito às leis estabelecidas para a boa realização das atividades produtivas. Trata-se, na minha perspectiva, de três instâncias que se acreditam irredutíveis umas às outras e, num outro sentido, como pressupondo-se mutuamente. Mas isso ainda quer dizer pouca coisa.

A sociedade civil cria uma esfera de atividades produtivas a partir das quais são supridas as necessidades dessa mesma sociedade e de seus membros (e/ou são criadas mais necessidades). Essa esfera é o mercado. No mercado, e por meio dele, todos os bens necessários ou considerados necessários ao desenvolvimento da vida humana e que efetivamente permitem uma lucratividade otimizada são produzidos para o consumo dessa mesma sociedade civil. $\mathrm{O}$ mercado é o lugar das atividades produtivas necessárias ou consideradas por experts como vitais para o desenvolvimento individual e social. Mas a sociedade civil não se reduz ao mercado. Depende dele, é verdade, mas não se reduz a ele. Assim, na sociedade civil, o indivíduo possui uma religião específica, torce para este ou aquele time, busca parceiras ou parceiros sexuais conforme seu desejo, gosta deste ou daquele tênis, etc. - enfim, na sociedade civil cada um segue sua vida do jeito que quiser. E também trabalha, produz, ou, se for desempregado, é sustentado pelo Estado - pelo menos naqueles países em que a seguridade social está consolidada efetivamente (nos outros, recebe um 
assistencialismo mais primário). E, por fim, o Estado, com suas leis e com sua força, garante o respeito aos direitos de cada cidadão e também o respeito e o cumprimento dos contratos ligados ao mercado e à consecução de suas (desse mesmo mercado) atividades. Então, uma democracia ocidental constitui-se de três instâncias, independentes e interdependentes: a sociedade civil, este contexto amplo no qual cada indivíduo segue sua vida do jeito que quiser, ou no qual os grupos seguem suas vidas a partir de suas concepções de mundo; o mercado, lugar das atividades produtivas, em que os membros da sociedade civil têm necessariamente de entrar para produzir e, conseqüentemente, para garantir sua sobrevivência; e o Estado, como o lugar em que esses mesmos membros da sociedade civil e/ou seus representantes efetivamente constroem as regras de caráter geral tanto para a convivência social e a proteção dos indivíduos e dos grupos de crenças quanto para as relações entre produtores, trabalhadores e consumidores no mercado. No caso da sociedade civil, portanto, sua amplidão impede-nos de caracterizá-la meramente como o lugar das atividades produtivas, já que ela é entendida como esse horizonte geral que é marcado por todos os aspectos da vida de cada indivíduo, de grupos e, portanto, da sociabilidade. $\bigcirc$ mercado é uma instância da sociedade civil, ainda que possa ser a mais importante e determinante: ele é o lugar das atividades produtivas. E o Estado se volta para a regulação tanto da sociabilidade quanto das atividades produtivas. Ora, é essa dependência ou essa interdependência entre tais instâncias que se me aparece como problemática.

Em primeiro lugar, há de se dizer que essa luta por descentralização política implicou em que a colocação dos 
indivíduos e de seus grupos como os detentores do poder político legítimo gerou um grande temor entre os liberais, idealizadores do Estado moderno (eu me refiro, entre outros, a John Locke, a Adam Smith e a Alexis de Tocqueville). Prova disso é que Locke, se é bem verdade que defendeu veementemente o direito de resistência, por outro lado apontou para os direitos naturais (Locke não considerava o direito de resistência como um direito natural) como um freio, como a base e o limite para aquele direito de resistência. Ou seja, para Locke, o direito de resistência somente teria legitimidade no instante em que os direitos naturais fossem violados; uma vez restabelecida a ordem, todo poder cabia ao parlamento, no Estado - e o direito de resistência perdia todo o sentido ${ }^{6}$. Adam Smith, por sua vez, atribuía a criação do Estado à necessidade de se proteger as atividades econômicas ${ }^{7}$. E, quase dois séculos depois de Locke, Alexis de Tocqueville, embora percebendo triste e resignadamente (ele que era um cavalheiro educado e que não concebia a política a não ser como uma atividade de ilustres senhores) a marcha acelerada do processo de democratização em sociedades ocidentais, o que redundaria não apenas no perigo do socialismo (que ele tanto temia), mas muito mais nisto que ele chamava de ditadura da maioria, ainda assim acreditava que instituições sólidas e boas leis minimizariam esse perigo de que a maioria se insurgisse, por exemplo, contra minorias. A grande questão, no caso de Tocqueville, estava em que o processo de democratização do poder político e mesmo a inclusão social traria

\footnotetext{
${ }^{6}$ Cf.: BOBBIO, Norberto. Locke e o Direito Natural, p. 197-206.

${ }^{7}$ SMITH, Adam. A Riqueza das Nações, Volume II, segunda parte ("Das Despesas com a Justiça"), p. 315.
} 
grandes desafios à conciliação entre os interesses dessas maiorias e os direitos das minorias - e, nesse sentido, embora a ditadura da maioria fosse um perigo constante, o fato é que o poder político encontrava um limite justamente no fato de ser realizado por representantes do povo no parlamento, e não mais na sociedade civil e por meio da revolução ${ }^{8}$. Mas essa é outra história, que não nos interessa aqui. $\mathrm{O}$ que eu quero expressar é que a descentralização política foi na verdade canalizada para a instauração de um poder político que efetivamente encontrou o seu lugar por excelência de realização no parlamento e por parte dos partidos políticos e dos políticos representantes dos grupos da sociedade civil. Esse poder político ainda seria realizado a partir da regra da maioria, mas em um lugar específico e por sujeitos políticos específicos: respectivamente, como eu disse acima, no parlamento pelos políticos e partidos políticos.

Vejamos bem. O Estado é essa instância colocada como central no que diz respeito à regulação da sociabilidade e do mercado (especialmente em se tratando da proteção e da necessidade de se fazer cumprir os pactos e os contratos). É dele que se irradiam as normas de caráter coletivo tanto para o respeito e a realização dos direitos de cada cidadão e, conseqüentemente, da estabilidade da sociabilidade quanto para o bom andamento das relações mercantis. A sociedade civil (lembremos do direito de resistência lockeano), o mercado (lembremos da mão invisivel de Adam Smith ${ }^{9}$ ) e o Estado manteriam sua especificidade, sua singularidade e sua independência, mas ainda assim se relacionariam pro-

\footnotetext{
${ }^{8}$ Cf.: TOCQUEVILLE, Alexis. A Democracia na América, Livro I, p. 11.

${ }^{9}$ Cf.: SMITH, Adam. A Riqueza das Nações, Volume I, 1999, livro III, capítulo II ("Do Desencorajamento da Agricultura no Antigo Estado da Europa após a Queda do Império Romano), p. 668.
} 
fundamente. E se relacionariam mutuamente a partir de um duplo movimento: o primeiro, que eu já caracterizei, é marcado pelo fato de o Estado moderno ser colocado como essa instância central a partir da qual se irradiam as coordenadas principais da socialização e da individuação, bem como da regulação das atividades mercantis (trata-se do movimento no qual o Estado intervém na sociedade civil e no mercado); o segundo, marcado pela participação de representantes da sociedade civil na deliberação acerca das decisões políticas a serem tomadas - é este o momento em que a sociedade civil como um todo perde seu caráter político ao transferi-lo para seus representantes. Eu digo perde, porque efetivamente o princípio básico possibilitador do Estado moderno foi, sem sombra de dúvidas, a sociedade civil revolucionária. Foi daqui que emanou uma práxis política que derrubou as estruturas do Antigo Regime e que possibilitou a paulatina instauração de instituições que apontavam para a soberania popular como esse princípio basilar de fundamentação da sociedade política. Ora, na exata medida em que a sociedade civil revolucionária deixa de ser a arena de uma práxis política efetiva, transferindo essa arena para os parlamentos, e no momento em que os movimentos da sociedade civil deixam de ser os atores políticos por excelência, transferindo seu poder de decisão para os partidos políticos e para os políticos seus representantes, se estabelece uma situação paradigmática para o desenvolvimento das democracias ocidentais, e isso até hoje: o momento em que os parlamentos e os partidos políticos e políticos profissionais são colocados, respectivamente, como a arena política legítima na qual e somente pela qual se realizariam as transformações sociais, e como os sujeitos políticos por excelência no que diz respeito à condução da 
evolução social. Esse é o momento definidor de toda a dinâmica das democracias ocidentais, na exata medida em que todas as decisões políticas somente são legítimas se forem tomadas no parlamento e pelos políticos e partidos políticos. Ora, se repararmos para os movimentos sociais dos séculos XIX em diante, o que veremos é que efetivamente ou lutaram contra aquele poder legítimo (parlamentos e partidos políticos e políticos profissionais) ou reivindicaram junto a ele melhora nas condições de vida das classes trabalhadoras. Mas o fato determinante dos rumos das democracias ocidentais é efetivamente este, ou seja, (1) a instauração de uma arena de realização da práxis política que está centralizada no parlamento e que se coloca como o espaço legal e legítimo (como o único espaço legal e legítimo) para a construção das determinações políticas e (2) a consolidação dos partidos políticos e dos políticos profissionais como esses sujeitos políticos que teriam por missão conduzir a evolução dessas mesmas democracias ocidentais. É assim que podemos perceber a lenta supressão e aniquilamento políticos da sociedade civil e de seus movimentos, na exata medida em que qualquer tentativa de influir na condução da evolução social, se não estivesse canalizada para a política representativa e parlamentar e se não fosse realizada pelos políticos e pelos partidos políticos profissionais, seria considerada ilegítima, marginal, ao mesmo tempo em que esses movimentos sociais seriam considerados como marginais, como banditismo, como grupos de foras-da-lei, etc. E essa situação em que o parlamento representativo e os partidos políticos e os políticos profissionais tomam as rédeas da práxis política e da condução da evolução social é tão importante e paradigmática que nós podemos perceber, a partir de meados do século XIX, que a 
sociedade civil e seus movimentos foram deslegitimados em sua práxis política, no sentido de que uma política desligada daqueles seria considerada ilegítima e, portanto, seus defensores tratados como caso de polícia. Nesse aspecto, as democracias ocidentais não permitem que a sociedade civil e seus movimentos se constituam em poderes paralelos ao próprio Estado democrático de direito. Este permite, sim, a mobilização social e a ação dos movimentos sociais, mas somente até o limite em que esta mobilização chegue ao parlamento, que é efetivamente o lugar da condução da transformação social. Nesse sentido, qualquer reivindicação que não seja levada à política parlamentar é ilegítima e, portanto, criminosa - o que equivale a afirmar que os movimentos sociais por si sós não têm condições de realizarem uma práxis política transformadora que não implique em colocar o parlamento e os partidos políticos e os políticos profissionais como, respectivamente, a arena e os sujeitos políticos da transformação social. O Estado democrático de direito não legitima uma práxis política que esteja para além de seus (desse Estado democrático de direito) muros e regras: a prova disso está em que todo movimento social, quando vai à rua reivindicar, é acompanhado passo a passo pela polícia.

2. Minha suspeita, que eu quero explicitar nesse artigo, está em que o desenvolvimento das democracias ocidentais colocou em segundo plano a força política da sociedade civil e, nesse sentido, retirou-lhe praticamente todo o seu poder de mobilização e de decisão política, transferindo o palco político para os parlamentos e seu (da sociedade civil) poder de decisão para os partidos políticos e para os políticos profissionais. É o que perseguirei no que se segue. 
Interessantemente, essa necessidade de frear o impulso revolucionário da sociedade civil não foi realizada pelo Antigo Regime, e sim pelo liberalismo clássico. E o mais interessante está em que o liberalismo clássico, tanto na sua variante política (John Locke) quanto na sua variante econômica (Adam Smith), apontou limites ao próprio Estado no que diz respeito ao que ele pode e ao que ele não pode fazer, mas muito mais apontou limites à própria sociedade civil e ao que ela pode ou não pode fazer politicamente.

Eu acredito, conforme já deixei explícito acima, que não poderíamos entender o sentido das revoluções modernas se não percebermos que, nelas, a sociedade civil e seus movimentos são, respectivamente, a arena da práxis política e os sujeitos políticos dessa práxis político-revolucionária. Desse modo, as revoluções modernas somente foram possíveis porque cortaram relações com a política considerada legítima e com o status quo necessário para se participar dessa práxis política considerada legítima. Se nós repararmos na Revolução Francesa, veremos que houve um corte radical com as regras elaboradas pelo Antigo Regime no que diz respeito à possibilidade de se participar em igualdade com o primeiro e segundo estados; quem fazia a revolução eram camponeses e trabalhadores urbanos, burgueses, intelectuais, etc. Portanto, esses movimentos revolucionários modernos eram fundamentalmente movimentos oriundos da sociedade civil e que faziam sua revolução a partir da sociedade civil, cortando qualquer relação com o Estado e suas regras, cortando qualquer relação com a política (no caso da Revolução Francesa, para o que aqui nos interessa nesse momento) legitimada institucionalmente como o único caminho válido para a realização das transformações sociais. As revoluções modernas ensinaram e, muito mais, 
consolidaram a sociedade civil e seus movimentos como, respectivamente, o lugar por excelência de uma práxis política independente e desligada dos freios da política institucionalizada, e como os sujeitos políticos por excelência, com condições de realizar transformações sociais de baixo para cima e recusando qualquer transformação vinda do alto. Não espanta, nesse sentido, a afirmação de Marx de que o que caracteriza a modernidade, muito mais do que a descoberta do indivíduo, seja efetivamente a consolidação da sociedade civil e de seus movimentos como o lugar e os sujeitos políticos por excelência da dinâmica política moderna $^{10}$.

Por outro lado, o fenômeno importantíssimo, na consolidação dos Estados modernos, está em terem canalizado para seu (desses mesmos Estados modernos) interior a condução das transformações sociais e, como conseqüência, o fato de terem engessado a sociedade civil e seus movimentos a partir de suas (dos Estados modernos) regras e de sua (dos Estados modernos) dinâmica política. As revoluções burguesas modernas é que instituíram essa lógica interessante: se por um lado dependeram fundamentalmente da sociedade civil e de seus movimentos para adquirirem preponderância política, por outro lado, na medida em que já dispunham dessa hegemonia, construíram todo um aparato legal e político que distanciou a tomada de decisões políticas da sociedade civil e dos movimentos desta. E mesmo a própria estruturação do Estado moderno, para citar uma situação muito importante, teve a seguinte característica: ele não poderia intervir na regulação das atividades econômicas

\footnotetext{
${ }^{10}$ Cf.: MARX, Karl; ENGELS, Friedrich. A Ideologia Alemã, p. 87-97; MARX, Karl. Manuscritos Econômico-Filosóficos, p. 45-59 ("Contribuição à Crítica da Filosofia do Direito de Hegel”).
} 
(a não ser que fosse para promovê-las), mas poderia intervir sempre, e com força, naqueles grupos e/ou indivíduos que entravassem ou que tentassem entravar a dinâmica dessas atividades, que pudessem causar desordem social. $\mathrm{O}$ Estado moderno tinha como objetivo manter um determinado status quo, e foi organizado para tal. Como já dizia Locke, há certos direitos naturais que devem ser garantidos por uma instância objetiva - e o Estado, que é essa instância objetiva, tem sua criação justificada apenas por causa disso, e para se evitar o relativismo no que diz respeito à aplicação da lei (ou seja, se cada indivíduo fizesse justiça por suas próprias mãos, teríamos um grande problema; já o Estado realiza a justiça de forma objetiva). Mas garantir a inviolabilidade desses direitos naturais implica em deixar claro os fins desse mesmo Estado: realizar a justiça punitiva a todos aqueles que violarem os direitos naturais dos outros. Qualquer outra função mais ampla está proibida a esse Estado. Ao mesmo tempo, implica em deixar claro o limite de ação dos próprios cidadãos: qualquer reivindicação que possa levar à violação dos direitos naturais é ilegítima e, portanto, deve ser reprimida. Nesse sentido, podemos fazer a mesma analogia em relação à aplicação da justiça com a questão da fundamentação política: se o Estado se justifica somente pela necessidade de aplicação objetiva da justiça, da mesma forma a fundamentação política não pode passar ao largo de uma arena objetiva e de representantes legitimados no que diz respeito à realização da práxis política - é por isso que a práxis política também precisa de um local legítimo para ser realizada convenientemente. Esse lugar, conforme já salientado acima, é o parlamento, com os partidos políticos e os políticos como os representantes legítimos dos cidadãos. E também aqui vale a mesma regra que é coloca- 
da ao próprio funcionamento do Estado: nenhuma política pública pode violar aqueles direitos naturais que são o fundamento do próprio Estado. Desse modo, tanto Estado quanto esfera política ficam engessados diante dessa idéia de direitos naturais. Isso por um lado faz sentido, afinal de contas minimiza o poder do Estado, que geralmente tende a ser como que absoluto e, como conseqüência, a oprimir e a anular indivíduos e grupos. Num outro sentido, entretanto, a própria formulação desses direitos naturais, ao considerar as desigualdades sociais e políticas como produtos da capacidade ou da incapacidade de cada um em produzir, e inclusive ao considerar essas atividades produtivas como atividades privadas eminentemente, na verdade o que faz é somente colocar ao Estado a tarefa de realizar justiça punitiva, de modo que esse Estado, muito mais do que mudar efetivamente as condições sociais em vista da inclusão de todos os indivíduos, o que faz é impedir qualquer mudança social, por mais que ela seja justificada pelo direito à realização desses direitos naturais para todos. Um Estado paradoxal, portanto. Ele é produto de uma revolução originária da sociedade civil e realizada por movimentos da sociedade civil, mas, uma vez hegemônico, corta todas as ligações com essa mesma sociedade civil, mantendo apenas esta (ligação) de garantir a realização da justiça punitiva a todos aqueles que violarem os direitos naturais dos membros dessa sociedade civil que efetivamente os possuem. De antemão, na instauração desse Estado, Locke já deixa claro que o Estado tem seu sentido justamente em impedir que os membros da sociedade civil façam justiça com suas próprias mãos. Ou seja, o Estado é instaurado justamente para fazer justiça de forma objetiva, isto é, para tirar o poder de fazer justiça da sociedade civil. Então, partindo desse racio- 
cínio, se pode perceber que a instauração do Estado moderno implica na retirada de todo poder político da sociedade civil, na exata medida em que se tem de evitar esse relativismo na aplicação da justiça, ou na exata medida em que se tem de evitar que cada um faça justiça com suas próprias mãos. $\mathrm{O}$ direito legítimo de fazer justiça pertence ao Estado, e não mais à sociedade civil. E a sociedade civil já não pode mais fazer justiça por si mesma porque dispõe de canais institucionais a partir dos quais seus clamores, se existirem, poderão ser externados a instâncias políticas representativas que (estas sim) têm por função, efetivamente, realizarem essas mudanças que tais instâncias considerarem legítimas. De antemão, entretanto, fica proibido à sociedade civil qualquer movimento no sentido de pôr em xeque as normas institucionais aceitas e aquela arena política representada pelo parlamento, com seus partidos políticos e políticos profissionais - arena política e sujeitos políticos que efetivamente têm a prerrogativa no que diz respeito à realização das transformações sociais.

Nesse aspecto, penso que Marx compreendeu melhor do que qualquer outro de seu tempo o solapamento e a anulação que a sociedade civil e seus movimentos estavam sofrendo. Marx percebia, em primeiro lugar, que efetivamente a sociedade civil e seus movimentos eram respectivamente a arena de uma práxis política revolucionária e os sujeitos políticos dessa mesma práxis política revolucionária, e percebia, nesse sentido, que a modernidade política se iniciou efetivamente quando a sociedade civil organizada derrubou as estruturas do Antigo Regime e instaurou instituições políticas de cunho democrático e universalista, que colocavam a soberania popular como esse elemento básico de fundamentação da própria sociedade 
política. Por outro lado, Marx percebia o engessamento da sociedade civil sob as regras da política liberal. Especificamente, Marx se dava conta da extrema limitação a que a política parlamentar e representativa, levada a cabo por partidos políticos profissionais e por políticos profissionais, conduzia a sociedade civil e seus movimentos. Nesse sentido, a sociedade civil moderna e seus movimentos paulatinamente encontram seu fim com a política liberal: ou seja, a política liberal, com sua ênfase na política parlamentar realizada por partidos políticos e por políticos profissionais, aniquila o poder dos grupos políticos da sociedade civil, ao mesmo tempo que retira dessa mesma sociedade civil a arena da práxis política, transferindo-a, como eu disse, ao parlamento.

Ora, mas essa situação de solapamento da sociedade civil e de seus movimentos, por parte do Estado liberal, implica em duas questões muito interessantes e importantes. A primeira delas está em que efetivamente a sociedade civil e seus movimentos deixam de ser respectivamente o espaço político por excelência e os sujeitos políticos por excelência, e em contrapartida temos a consolidação do parlamento e dos partidos políticos profissionais e dos políticos profissionais como respectivamente a arena política e os atores políticos por excelência. Isso equivale ao fato de o Estado liberal moderno voltar a entender a sociedade civil como o espaço por excelência no qual o determinante são as atividades produtivas e ao fato de cada indivíduo e grupo seguirem sua vida do jeito que quiserem, mas sem comprometimento político direto. Ou seja, a sociedade civil, tal qual concebida pelo liberalismo clássico, é totalmente separada, desligada do horizonte político, no sentido de um corte radical com qualquer forma de ligação e de participa- 
ção com a práxis política. É por isso que já não é permitido, aos cidadãos da sociedade civil, qualquer intervenção que parta dessa mesma sociedade civil em relação ao horizonte político: para isso há a mediação dos partidos políticos e dos políticos profissionais. Todas as transformações encontram seu lugar no parlamento por meio dos partidos políticos e dos políticos profissionais. A segunda questão está em que as revoluções sociais modernas, na exata medida em que tiveram a sociedade civil e seus movimentos, respectivamente, como a arena política e como os sujeitos políticos por excelência, praticaram uma política marginal que, portanto, estava desligada da política considerada legítima porque institucionalizada. Ora, mas não somente praticaram essa política às margens, como também defenderam abertamente a descentralização política como requisito básico contra a instauração de um Estado-Leviatã com poderes absolutos e opressor em relação aos movimentos dessa mesma sociedade civil. Portanto, em sua gênese e em sua luta, a sociedade civil se contrapôs a qualquer centralização política excessiva, o que equivale a afirmar que essa mesma sociedade civil e seus movimentos sempre se acreditaram como os únicos sujeitos políticos legítimos no que diz respeito à realização da práxis política. Mas é exatamente a isso que o Estado liberal moderno procura pôr fim, isto é, o Estado moderno, ao retirar da sociedade civil a arena política por excelência, e ao retirar dos movimentos da sociedade civil o poder legítimo de transformação social, transferindo essa arena para o parlamento e esse poder legítimo de transformação social para os partidos políticos e para os políticos profissionais, retira da sociedade civil e de seus movimentos qualquer força política e, em contrapartida, ao engessá-los sob o jogo da política parlamentar e representativa, volta a 
caracterizar-se como um Estado todo-poderoso, com poderes de vida e de morte sobre todos os cidadãos e com um poder absoluto sobre a sociedade civil.

O Estado liberal é um Estado-Leviatã por dois motivos básicos: em primeiro lugar, por canalizar para si a legitimidade e o espaço de legitimidade no que diz respeito à condução da evolução social, retirando esse poder legítimo da sociedade civil e de seus movimentos; em segundo lugar, ao concentrar em si os poderes de vida e de morte sobre toda a sociedade civil e seus membros, o que equivale a dizer que é esse mesmo Estado - e somente ele - que tem a legitimidade no que se refere à realização da justiça punitiva, corretiva, a toda a sociedade civil. Mas interessantemente o Estado liberal somente realiza a justiça punitiva, que decorre da maneira sui generis a partir da qual ele concebe a origem das desigualdades sociais e políticas: justamente por entender as atividades produtivas como atividades privadas, esse mesmo Estado pode eximir-se de qualquer responsabilidade social no que diz respeito à regulação dessas atividades, e mesmo no que diz respeito à correção dessas desigualdades. É aqui que mais do que nunca pode ser entendida historicamente a questão da mão invisível de Adam Smith, no sentido de que somente num contexto no qual se compreende as atividades econômicas capitalistas como atividades meramente privadas é que se pode defender que no mercado, por meio do trabalho egoísta de cada um, se consegue a satisfação das necessidades de todos e, portanto, como conseqüência, de que o Estado tem de ser um Estado de laissez-faire, que não intervém na esfera produtiva.

Marx, nesse sentido, sempre atacou veementemente essa dupla característica do Estado liberal, a saber, seu poder absoluto, que neutralizava por completo a sociedade civil e 
seus movimentos sob o jogo da política representativa e parlamentar, e que inclusive retirava o poder político dos movimentos sociais, transferindo-o para os partidos políticos e para os políticos profissionais; e o comprometimento do Estado liberal com a manutenção de uma economia excludente e desigual, que no seu próprio exercício era concentrada cada vez mais em poucas mãos, o que implicava, como conseqüência, na marginalização crescente de amplas camadas da população e na concentração do aparato político nas mãos exclusivas da burguesia. Fundamentalmente, eu tendo a entender Marx como o pensador da sociedade civil e de seus movimentos, que pretendeu resgatar o potencial político revolucionário dessa mesma sociedade civil e de seus movimentos contra uma política parlamentar e representativa centralizada nos parlamentos e realizada exclusivamente pelos partidos políticos e pelos políticos profissionais. Ele percebia a profunda contradição entre a formulação de um Estado fundado, em teoria, na liberdade e na igualdade entre todos e a realidade de uma separação gritante entre sociedade civil e sociedade política; e, num outro sentido, percebia a ligação intrínseca entre o controle ideológico e repressivo da sociedade civil por parte do Estado liberal e a necessidade de proteção de uma acumulação capitalista que tinha necessariamente de ser garantida a qualquer preço pelo próprio Estado liberal. No primeiro caso, então, a negação por parte do Estado liberal de que a sociedade civil fosse também a sociedade política por excelência implicava na completa despolitização dessa mesma sociedade civil e na completa politização do Estado, mas agora sob a batuta dos partidos políticos e dos políticos profissionais. No segundo caso, o Estado-Leviatã liberal, marcado fundamentalmente pela doutrina do laissez- 
faire, se não poderia influir diretamente nas próprias atividades econômicas, tinha, por outro lado, de intervir diretamente no controle e na formação das massas como condição da própria estabilidade da sociedade e do próprio funcionamento dos mercados. Mas o fato claro da modernidade política está em que, se essa mesma modernidade somente foi possível por meio de uma práxis política revolucionária por parte da sociedade civil e de seus movimentos, por outro lado, com a consolidação do Estado liberal, nós temos a radical separação entre sociedade civil e sociedade política, o que significa que a sociedade civil e seus movimentos foram anulados politicamente falando, ocasionando-se a instauração de uma política parlamentar e representativa na qual qualquer legitimidade no que diz respeito à condução da evolução social cabia aos partidos políticos e aos políticos profissionais.

3. Os movimentos sociais, que a partir de Marx tomaram a cena política européia e se espalharam pelas sociedades ocidentais, lutaram efetivamente contra esse Estado que congrega em si - e, portanto, que retira da sociedade civil todo poder de transformação social, lutaram contra um regime político que coloca os partidos políticos e os políticos profissionais como os sujeitos políticos por excelência da transformação social. A consolidação das democracias ocidentais efetivamente esteve marcada, em seu processo, em seu desenvolvimento, por essa luta entre movimentos sociais que reivindicavam espaço e poder políticos amplos para si e por um parlamento liberal (e até oligárquico) que recusava qualquer forma alternativa de transformação social que não a alternativa parlamentar, fundada no jogo dos partidos políticos e dos políticos profissionais. 
Ora, com a instauração e a consolidação das democracias sociais a partir da década de 1940, nós temos uma reformulação nos rumos do Estado liberal. A questão central ali ainda era a de garantir patamares cada vez mais altos de acumulação como condição de tudo o mais - e esse Estado liberal investia maciçamente em infra-estrutura e na conquista de mercados externos para garantir esses padrões. Mas a essa questão central foi acrescentada a realização dos direitos sociais de cidadania e, portanto, a integração das classes trabalhadoras no consumo a partir da garantia de um padrão mínimo de vida material a todos, abaixo do qual ninguém poderia cair. Nós temos aqui a emergência da democracia de massas, que tem por base um mercado de massas fundado no consumo de massas ${ }^{11}$. Com a democracia de massas, as classes trabalhadoras tiveram garantida a manutenção de padrões de consumo cada vez mais altos - o que implicou na sua inclusão ao sistema capitalista.

Mas a idéia que eu quero defender ao terminar esse trabalho está em que com a democracia de massas os cidadãos e as cidadãs das democracias ocidentais efetivamente têm, efetivamente conseguiram democracia social, mas não conseguiram, mas não têm democracia politica. Ora, fica claro que, não obstante o grau de inclusão social ser maior ou menor a partir da especificidade de cada democracia, todas as democracias ocidentais realizam tal inclusão social em algum aspecto, e fica claro até que essas mesmas democracias caminham em vista da realização desse objetivo de inclusão social (mas, note-se bem, inclusão por meio do consumo e da

\footnotetext{
${ }^{11}$ Cf.: HABERMAS, Jürgen. Mudança Estrutural da Esfera Pública, p. 287-288; HORKHEIMER, Max \& ADORNO, Theodor. Dialética do Esclarecimento, p. 117-125; MARCUSE, Herbert. A Ideologia da Sociedade Industrial, p. 23.
} 
escolarização; e, nas democracias mais deficitárias em termos de justiça social, inclusive por meio de assistencialismo mais primário). $\mathrm{O}$ que não acontece é justamente a inclusão política, a democracia política, no sentido de que estamos cada vez mais longe da arena política, por causa de uma política parlamentar e representativa que efetivamente privatiza a participação dos movimentos sociais e o exercício ativo da cidadania política por parte de cada cidadão e de cada cidadã. Se acrescentarmos a esse quadro a tendência à centralização e à privatização da esfera pública por parte dos grandes meios de comunicação e a tendência à concentração do poder político por parte dos grandes grupos econômicos ${ }^{12}$, então teremos uma imagem clara de que efetivamente as democracias ocidentais propiciam a seus cidadãos democracia social, inclusão social, mas não propiciam democracia política, inclusão política. Exatamente por isso, a sociedade civil e seus movimentos, hoje mais do que nunca, são anulados politicamente falando e, ao passo que os indivíduos conquistam cada vez mais inclusão no mercado, no trabalho e no consumo, por outro lado os cidadãos e as cidadãs perdem radicalmente seu poder de participação política ativa. Como está no título do texto, trata-se do ocaso da cidadania política, o que implica em afirmarmos o ocaso da própria sociedade civil e de seus movimentos. A democracia liberal, com suas transformações históricas (de um Estado de laissez-faire para um Estado de bem-estar social) garantiu democracia social, inclusão social a todos os indivíduos, mas não garantiu inclusão política, não realizou cidadania política a todos os cidadãos e a todas as cidadãs, ou seja, anulou o potencial político da sociedade civil e de

${ }^{12}$ Cf.: HABERMAS, Jürgen. Mudança Estrutural da Esfera Pública, p. 270. 
seus movimentos por meio do jogo da política representativa e parlamentar e dos partidos políticos e dos políticos profissionais. A grande contradição de nosso tempo - e os movimentos sociais e socialistas provavelmente não se deram conta disso - está em que temos efetivamente democracia social, mas não temos democracia política e, portanto, de que a sociedade civil e seus movimentos perderam como que por completo seu potencial políticorevolucionário. Mas o que sobra para a política? Qual o futuro de uma democracia social? Certamente nos encontramos ante um paradoxo ou dificuldade impensável para Marx: é que ele acreditava que a democracia social seria a pedra angular para a realização e a efetivação da democracia política, mas a minha suspeita está em que é a democracia política que se constitui em condição fundamental para a democracia social, no sentido de que não basta a inclusão social no mercado, no lazer e no consumo para construirmos uma democracia radical, mas sim, na minha perspectiva, a efetividade da cidadania política é absolutamente essencial para realizarmos não somente a democratização política, mas também a democratização social. Ora, mas isso não conseguiremos em nossas democracias sem a reativação da sociedade civil e de seus movimentos como respectivamente o espaço político e os sujeitos políticos de uma práxis política emancipatória - e isso contra a política parlamentar e representativa privatizada no parlamento pelos políticos e partidos políticos profissionais. De todo modo, o modelo de democracia social, de inclusão social que temos em nossas sociedades democráticas ocidentais, se por um lado estabelece a necessidade de um padrão mínimo de vida material a todos e a todas, abaixo do qual ninguém pode cair, por outro lado é 
um dos elementos ideológicos mais importantes que contribui para a perda de efetividade da cidadania política, que contribui para o esquecimento social do valor inestimável da cidadania política.

Abstract: This paper discusses about the evolution of western democracies. It will defend that the consolidation of liberal State denied the power of civil society and it's movements as public sphere and political agents of social transformation. It aims to point that liberal state hegemony denied political power of civil society and its movements. Therefore, I want to defend that, with hegemonic classical liberal state we have the washout of political power of the civil society and its movements; social democracies of welfare states that depend of liberal state - are characterized by social democracy, but not political democracy.

Keywords: civil society, social movements, liberal state, democracy.

\section{REFERÊNCIAS}

ARON, Raymond. As Etapas do Pensamento Sociológico. Tradução de Sérgio Bath. São Paulo: Martins Fontes, 2008.

BOBBIO, Norberto. Locke e o Direito Natural. Brasília: Editora da Universidade de Brasília, 1998.

CONSTITUIÇÃO AMERICANA. Disponível em: http://www.usconstitution.net/const.html Data de acesso: 10/12/2009.

HABERMAS, Jürgen. Mudança Estrutural da Esfera Pública: Investigações quanto a Uma Categoria da Sociedade Burguesa. Rio de Janeiro: Tempo Brasileiro, 1984.

HORKHEIMER, Marx; ADORNO, Theodor. Dialética do Esclarecimento: Fragmentos Filosóficos. Rio de Janeiro: Jorge Zahar Editor, 1985. 
LOCKE, John. Segundo Tratado sobre o Governo Civil. Tradução de Julio Fischer. São Paulo. Martins Fontes, 2005.

MARCUSE, Herbert. A Ideologia da Sociedade Industrial. Rio de Janeiro: Jorge Zahar Editor, 1978.

MARX, Karl. Manuscritos Econômico-Filosóficos. Tradução de Alex Marins. São Paulo: Edições Martin Claret, 2006.

MARX, Karl; ENGELS, Friedrich. A Ideologia Alemã. Tradução de Luis Claudio de Castro e Costa. São Paulo: Martins Fontes, 2008.

MONTESQUIEU, Charles Louis de Secondat, Barão de. O Espírito das Leis. São Paulo: Abril Cultural, 1973.

SMITH, Adam. A Riqueza das Nações (Volumes I e II). Tradução e Notas de Teodora Cardoso. Lisboa: Fundação Calouste Gulbenkian, 1999.

TOCQUEVILLE, Alexis. A Democracia na América (Livro I): Leis e Costumes. São Paulo: Martins Fontes, 2005. 